\title{
SAMOEFIKASNOST, PROBLEMSKA NASTAVA I VEŠTINA PISANJA
}

APSTRAKT: Teorija samoefikasnosti zasnovana je na ideji važnosti ličnog doživljaja sopstvenih sposobnosti pri realizaciji različitih ciljeva i zadataka. Rad ima za cilj da ispita uticaj problemske nastave (engl. problem-based learning) na razvoj samoefikasnosti studenata. U radu analiziramo razlike u samoproceni studenata o poboljšanju lokalnih i globalnih aspekata pisanja, uz korišćenje problemske nastave u okviru engleskog jezika struke. Rezultati pokazuju da problemska nastava ima pozitivan uticaj na percepcije učenika o razvoju veštine pisanja na kursu engleskog jezika struke. Razvoj samoefikasnosti u velikoj meri određuje ponašanje studenata u ostvarivanju cilja jer pokreće akciju, određuje količinu napora koji treba uložiti, istrajnost pri suočavanju s preprekama i način na koji student reaguje na neuspeh u procesu učenja.

Ključne reči: samoefikasnost, problemska nastava, nastava pisanja, lokalni i globalni aspekti pisanja.

\section{SELF-EFFICACY, PROBLEM-BASED LEARNING AND WRITING SKILLS}

ABSTRACT: The theory of self-efficacy is based on the idea of the importance of personal judgement of one's own abilities in the realization of different goals and tasks. The paper aims to examine the influence of problem-based learning on the development of students' self-efficacy. This paper analyzes the differences in self-evaluation of students about improving local and global aspects of writing, using problem-based learning and traditional teaching in an ESP writing course. The results show that problem-based teaching has a positive impact on student perceptions on the development of professional writing skills. The development of self-efficacy largely determines students' behaviour in achieving the goal by triggering the action, determining the amount of effort to be invested, perseverance in dealing with obstacles, and the way in which a student reacts to failure in the learning process.

Key words: self-efficacy, problem-based learning, teaching writing, local and global aspects.

\section{UVOD}

Počev od 1977. godine, kada je Albert Bandura uveo koncept samoefikasnosti, ova problematika biva predmet razmatranja različitih teoretičara i istraživača. Po Banduri, samoefikasnost (engl. self-efficiency) odnosi se na lična uverenja - samoprocenu (engl. self-evaluation) učenika o njihovim sposobnostima 
za učenje ili izvođenje određene veštine na različitim nivoima i igra važnu ulogu u njihovoj motivaciji i uspehu u učenju. Samoefikasnost je ključni mehanizam u socijalnoj kognitivnoj teoriji, koji postulira da postignuće zavisi od interakcije tri tipa faktora - ponašanja, ličnih faktora (kognitivni, emocionalni i biološki) i faktora okoline. Učenici formiraju svoja uverenja samopouzdanja tumačenjem informacija prvenstveno iz četiri izvora (Bandura, 1997) a to su: (1) Lična iskustva - uspeh u prethodnim, istim ili sličnim situacijama ojačaće veru u samoefikasnost, a neuspeh će je umanjiti. Neuspesi u ranim fazama narušavaju verovanje u sopstvenu efikasnost, ali ako se osoba suočava samo sa lako postignutim uspesima, ona se lako obeshrabri u slučaju neuspeha. (2) Psihofizička stanja tokom obavljanja zadatka - stanja prijatnosti u situacijama kada osoba realizuje željenu aktivnost učvrstiće osećaj sigurnosti, dok se neprijatna stanja u okolnostima kada se izvršava aktivnost vezuju za osećaj manje kompetentnosti. Dakle, kada se suočimo sa nekim zadatkom, možemo biti anksiozni i zabrinuti (što utiče na pad efikasnosti) ili uzbuđeni i energični (što utiče na porast efikasnosti). (3) Posredno iskustvo, učenje po modelu - iskustva drugih ljudi omogućavaju učenje sa jedne strane i poređenje svojih i tuđih sposobnosti sa osobama istih ili sličnih sposobnosti sa druge strane. Ako osoba vidi druge da postižu uspeh pribegavanjem sličnim strategijama, počinje verovati da, takođe, poseduje kapacitete za uspeh. Posmatranje tuđih neuspeha dovodi do sumnje u vlastite sposobnosti u vezi sa sličnim aktivnostima i (4) socijalnih reakcija referentnih osoba (roditelja, nastavnika, vršnjaka $i$ sl.). Poslednji navedeni izvor može uticati na pojedinca tako što će on uložiti veći napor da bi ostvario neki cilj ili će isprobati nove strategije u radu. Ako su osobu ohrabrivali i uveravali da može uspešno obaviti neku aktivnost, ona će uložiti više napora nego osoba koja ne dobija takvu vrstu podrške.

Dakle, subjektivni doživljaj sopstvene vrednosti podjednako je važan kao i stvarne sposobnosti. Iako su stvarne sposobnosti neophodne, nisu i dovoljne da bi osoba izvela neku akciju ili rešila određeni zadatak. Za uspeh su potrebna i uverenja da će se stvarne sposobnosti moći efikasno upotrebiti. Brojna istraživanja (Pajares \& Johnson, 1996; Broaddus, 2012; Shah et al., 2011) ukazuju na značaj poverenja u svoje sposobnosti na veštinu pisanja na stranom jeziku. Ipak, nema puno istraživanja koja povezuju razvoj samoefikasnosti, veštinu pisanja sa određenim nastavnim metodama, u čemu upravo leži najveći doprinos ovog istraživanja.

\section{SAMOEFIKASNOST I VEŠTINA PISANJA}

Rezultati brojnih istraživanja sugerišu da je samopouzdanje učenika u njihovu sposobnost pisanja ključno za njihov uspeh kao pisaca (Pajares \& Johnson, 1996) jer je samouverenost blisko povezana sa motivacijom učenika.

Kako tvrde Pajares i Džonson (Pajares \& Johnson, 1996), samopouzdanje studentima pomaže da se utvrdi šta oni rade sa znanjem i veštinama koje imaju. Navedeni autori su u ovoj studiji zaključili da studenti koji pokazuju pozitivan stav prema pisanju češće pišu i ulažu više napora u pisanje zadataka nego njihovi 
vršnjaci koji ispoljavaju negativan stav prema istim zadacima. Pajares i Džonson (Pajares \& Johnson, 1996: 163) su utvrdili da stavovi studenta o sopstvenoj efikasnosti „posreduju na uticaj drugih faktora na postignuće u pisanju”, kao što su njihove odluke o obimu teksta koji će napisati, o složenosti pisanja, o uloženom vremenu za pisanje određene teme, kao i o stepenu razvijenosti teme. Pajares i Valiante (Pajares \& Valiante, 1997) su ispitivali učenike petog razreda i utvrdili da nivo poverenja u sopstvene veštine pisanja precizno predviđa njihov ukupni učinak pisanja na maternjem i stranom jeziku. Smatraju da, kada učenici imaju dovoljno samopouzdanja u svoju sposobnost pisanja na svom drugom jeziku, pokazuju veću zainteresovanost i želju i ulažu konstantne napore prilikom pisanja pismenih radova.

Ideja da samoprocena efikasnosti utiče na performanse, to jest, da poverenje studenata u sopstvene sposobnosti određuje šta će uraditi sa znanjem ili veštinama koje poseduju, navela je Šela i saradnike (Shell, Murphy \& Bruning, 1989) da ispitaju vezu između poverenja studenata u sopstvene veštine i veštine pisanja na maternjem jeziku. Utvrdili su izrazito visoku korelaciju između poverenja studenata u sopstvenu veštinu pisanja i ocena na pismenim zadacima.

U studiji koju je 2012. godine sproveo, Brodus (Broaddus, 2012) je zaključio da su studenti novinarstva, koji su pokazali visoku samopouzdanost u svoje poznavanje gramatike, uložili više napora, bolje organizovali vreme i resurse pri izučavanju određene teme. Ustanovljeno je, takođe, da je ovakav visok stepen poverenja $u$ sopstvene veštine $\mathrm{i}$ poznavanje gramatike rezultirao boljim gramatičkim sposobnostima. Autor je zaključio su studenti koji su sigurni u svoje znanje lakše uspeli da odrede gde se nalazi izazov ili prepreka vezana za zadatak i da razviju strategije kako bi postigli uspeh u svojim pismenim radovima.

Šah i saradnici (Shah et al., 2011) su sproveli istraživanje sa učenicima jedne srednje škole u Maleziji kako bi utvrdili vezu između samoprocene učenika i njihove veštine pisanja. Rezultati su pokazali da postoji zaista velika i značajna pozitivna korelacija između poverenja u sopstvenu veštinu pisanja i same veštine pisanja. To jest, ponovo je potvrđeno da učenici sa visokim nivoom poverenja $u$ sopstvene sposobnosti imaju tendenciju da ,tragaju za prilikama da se pismeno izraze, ulažu više napora prilikom procesa pisanja i da su istrajniji u sticanju pismenih sposobnosti”.

Drugo istraživanje (Early \& De Costa-Smith, 2011) potvrdilo je Bandurinu socijalnu kognitivnu teoriju. Drugim rečima, samopouzdanje se stiče ličnim i posrednim iskustvima, kao i dobijanjem potvrde od članova zajednice kojoj pripadamo. Brojne mogućnosti za primenu bilo kog žanra, zajedno sa povratnim informacijama od strane vršnjaka ili nastavnika i interakcija tokom nastave mogu igrati ključnu ulogu u povećanju poverenja učenika $u$ njihovo poznavanje određenog žanra.

Rahimpur i Jahan (Rahimpour i Jahan, 2010) su tvrdili da su se sva prethodna istraživanja uglavnom fokusirala na istraživanje samoefikasnosti među grupama sa vrlo ograničenim nivoom znanja. Zbog toga su Rahimpur i Jahan 
odredili svoje istraživačko područje kao „uticaj samopouzdanja na pismene zadatke učenika koji uče engleski kao strani jezik u pogledu kognitivnog opterećenja (engl. load), tečnosti (engl. fluency), složenosti (engl. complexity) i tačnosti (engl. accuracy)". Izabrani učesnici bili su različitih nivoa znanja engleskog jezika, starosti od 18 do 25 godina. Pored pisanja tri odvojena zadatka, od učesnika je zatraženo da popune upitnik za procenu samoefikasnosti. Rezultati pokazuju da je postojao značajan odnos između samoefikasnosti i pismenih zadataka u pogledu kognitivnog opterećenja kod učenika sa višim nivoom znanja. Međutim, nije postojala značajna veza kada je reč o tečnosti, složenosti i tačnosti za podgrupe učenika sa nižim i višim nivoom znanja.

Bilo da je visoka ili niska, samoefikasnost u pisanju ima presudnu ulogu u nastavi pisanja i skreće pažnju da kontekst često utiče na efikasnost. U formalnom okruženju za učenje jezika, u kojem se može pisati samo ograničeno vreme, neophodno je pružiti dodatnu pomoć studentima sa niskom samopouzdanošću kako bi razvili veštine pisanja. Nastavnici ne bi trebalo da daju primere samo standardnih tehnika pisanja i pružaju korektivne povratne informacije o upotrebi jezika i gramatike, već je neophodno i pružanje individualne pomoći. Ipak, prema Brodusu, količina pomoći koju pružaju nastavnici takođe treba da bude ograničena. Autor citira Banduru (Bandura, 1997, prema Broaddus, 2012: 38) i navodi: „Uspesi koji su postignuti uz pomoć spoljne pomoći imaju malu vrednost na samoprocenu efikasnosti jer će verovatno biti pripisani spoljašnjim uticajima a ne ličnim sposobnostima".

\section{PROBLEMSKA NASTAVA}

Problemska nastava (engl. problem-based learning or PBL) sledi društveno-konstruktivističku perspektivu u nastavi gde je uloga nastavnika da vodi proces učenja, a ne samo strogo pružanje znanja. Tako su, u skladu sa navedenom perspektivom, povratna informacija i refleksija na proces učenja i dinamiku grupe osnovne komponente problemske nastave. Studenti treba da budu aktivni agenti koji se bave sticanjem socijalnog znanja. Problemska nastava pomaže izgradnju ličnih tumačenja sveta, na osnovu iskustva i interakcije (Hmelo-Silver \& Barrows, 2006).

U konceptu problemske nastave najvažnije je pitanje ko je fokus i na kome je odgovornost procesa učenja. Vejmer (Weimer, 2002) sumira tradicionalnu metodu i ističe da nastavnik određuje sadržaj, iznosi sadržaj, vodi raspravu i sumira ključne koncepte. U problemskoj nastavi fokus se pomera na studente, daje im snagu u okruženju, koje ne samo da im dozvoljava već i očekuje preuzimanje odgovornosti za sopstveno učenje. Prema Hmelo-Silver (Hmelo-Silver, 2004), problemska nastava je sistem nastave gde studenti o datoj temi uče u kontekstu složenih, višeslojnih i realnih problema. Ciljevi problemske nastave su da studentima pomognu da razviju fleksibilna znanja, veštine efikasnog rešavanja problema, efikasne saradnje i unutrašnju motivaciju. 
Pored navedenih, smatra se da problemska nastava podstiče unutrašnju motivaciju i orijentaciju na uspešno ostvarivanje cilja (engl. mastery-goal orientation), koji su u uskoj vezi sa samoefikasnošću. Prema Stepanovnoj (Stepanovna, 2000) motivacija je sastavni deo problemske nastave. Motivacija, takođe, može da proistekne iz emotivnog zadovoljstva. Ono leži u snazi donošenja odluke koje je rešenje problema najbolje i radosti interaktivnog uzbuđenja. Kada je u pitanju unutrašnja motivacija, ljudi nisu samo zainteresovani, već se osećaju i kompetentno i odlučno.

\subsection{Problemska nastava i samoefikasnost}

Pored navedenih, jedan od obrazovnih ciljeva problemske nastave jeste i razvoj veštine samoregulisanog učenja (engl. self-regulated learning). Samoregulisano učenje definisano je kao ,proces u kome pojedinci preuzimaju inicijativu u dijagnostikovanju svojih potreba učenja, formulisanju ciljeva, izboru i primeni odgovarajućih strategija učenja, kao i ocenu ishoda učenja" (Loiens, Magda \& Rikers, 2008). Problemska nastava poboljšava samoregulaciju (engl. selfregulated learning), a samoefikasnost je deo samoregulacije na više načina (Bandura, 1986, 1997). Pored određivanja ciljeva koji pomažu da regulišemo naše akcije, misli, emocije i ostvarimo željene rezultate, samoregulacija omogućava da se u odsustvu spoljnih mehanizama regulacije ponašanja, osoba može osloniti i na interne procese samoprocene. Prvenstveno, procena samoefikasnosti utiče na samoregulaciju, jer ukoliko je osoba ubeđena u svoju efikasnost, bolje će reagovati na neuspeh $i$ istrajati u ostvarenju željenih ciljeva, a potom će, ostvareni uspeh uvećati osećaj efikasnosti. Samoregulacija nije moguća bez procene samoefikasnosti, jer da bi učenik mogao regulisati svoje ponašanje u skladu sa strategijom koja ga može dovesti do cilja, neophodno je da vrednuje vlastite sposobnosti za ostvarivanje cilja (samoefikasnost). Uz to, samoregulacija podrazumeva i stalnu samoprocenu napretka, kao i mogućnost menjanja strategije ili cilja (Bandura, 1986). Samoprocena napretka koji postižemo ili ne postižemo prema zadatim ciljevima značajna je determinanta emotivnih reakcija tokom obavljanja konkretne aktivnosti. Snažna uverenost u efikasnost i ostvarivanje cilja, obično proizvodi emotivna stanja zadovoljstva koja, zauzvrat, poboljšavaju samoregulaciju, dok uverenost u neuspeh produkuje uznemirujuća emotivna stanja koja mogu uzrokovati kognitivnu i bihejvioralnu neefikasnost $\mathrm{i}$ neuspeh $\mathrm{u}$ samoregulaciji.

\subsection{Problemska nastava i nastava pisanja engleskog jezika}

Problemska nastava može se generalno vezati za komunikativni pristup učenju jezika (engl. Communicative Language Teaching), jer studentima nudi mnogo mogućnosti da komuniciraju na stranom jeziku koji se uči. Prema Mardziji Hajati Abduli (Abdullah, 1998: 2), tokom procesa učenja kroz rešavanje problema 
studenti koriste strani jezik da bi dobili i preneli informacije, izrazili mišljenja i pregovarali. Dok vode diskusije i donose odluke, konsultuju referentni materijal, razgovaraju jedni s drugima, uče da slušaju, govore, čitaju i pišu efikasno. Oni razvijaju vokabular, uče gramatička pravila i društvene konvencije upotrebe jezika i integrišu korišćenje različitih sistema znakova. Ukratko, konstruišu razumevanje jezika koji se koristi u situacijama iz stvarnog života.

Zatim, motivacija olakšava proces učenja jezika, a aktivnosti u učionici treba da budu svrsishodne i smislene, tako da studenti prepoznaju njihovu vrednost u procesu učenja. Problemska nastava stvara prijatna osećanja, uslove za pojavu realne „situacije uspeha" studenta u obrazovnom prostoru školske ustanove, odnosno takve nastavne situacije u kojima se student oseća kao pobednik, osvajač teško dostupnog vrha, istraživač novih predela. Važno je da svaki student doživi situaciju zasluženog uspeha, lične pobede, makar i najmanje; to će doprineti stvaranju osećanja o sopstvenoj vrednosti i ugleda u očima vršnjaka (Stepanovna, 2000: 118).

Pojedini pristupi u nastavi engleskog jezika, kao što su učenje usmereno na zadatak (engl. task-based learning) i učenje putem otkrića (engl. inquiry learning), sadrže ciljeve problemske nastave, kao što su saradnja, istraživanje i kritičko razmišljanje. Međutim, njihova upotreba se fundamentalno razlikuje od učenja zasnovanog na rešavanju problema. Problemi predstavljeni u kombinaciji sa zadatkom generalno su strukturirani i izabrani od nastavnika kako bi se ponovila željena funkcija jezika nakon što je ona predstavljena. Iako ova tehnika koristi probleme kao osnovu za motivisanje studenata da koriste strani jezik, ona funkcioniše u veoma tradicionalnom nastavnom formatu ,prezentacija - vežbanje produkcija" i postoji, u stvari, vrlo malo samostalnog rada studenata (Barron, 2002: 305). Učenje putem otkrića je aktivan pristup fokusiran na istraživanje, kritičko razmišljanje i rešavanje problema, a osnovna razlika između problemske nastave $\mathrm{i}$ učenja putem otkrića odnosi se na ulogu nastavnika. U istraživačkom pristupu nastavnik vodi proces učenja i pruža informacije. U problemskoj nastavi nastavnik podržava proces, ali ne daje informacije koje se odnose na problem - one su odgovornost studenta (Schwarzer \& Luke, 2001: 89).

Takođe, studije slučaja i projektna nastava su nastavne strategije koje se koriste u nastavi stranih jezika, koje promovišu aktivno učenje i angažuju studente $u$ razmišljanju višeg reda (engl. higher-order thinking) kao što su analiza i sinteza. Džon R. Sejveri (Savery, 2006: 15) navodi sličnosti projektne nastave, studija slučaja i učenja putem rešavanja problema - sva tri pristupa sastoje se od aktivnosti učenja organizovane oko postizanja zajedničkog cilja. U okviru njih, studenti obično dobijaju specifikacije za željeni krajnji proizvod i proces učenja više je orijentisan na praćenje niza ispravnih postupaka. Tokom rada na projektu studenti će verovatno sresti nekoliko „problema” koji stvaraju ,poučne trenutke”. Nastavnici treba da obezbede stručno vođstvo, povratne informacije i predloge boljih načina za postizanje finalnog proizvoda. Ipak, navodi Sejveri (Savery, 2006: 16), dok su slučajevi i projekti odlične nastavne strategije usmerene na studenta, oni često 
smanjuju ulogu studenta u postavljanju ciljeva i ishoda za „problem”. Kada su jasno definisani očekivani rezultati, postoji manja potreba ili podsticaj za studenta da postavi sopstvene parametre, a zna se da je sposobnost da se definiše problem i razvije rešenje (ili opseg mogućih rešenja), izuzetno važna u stvarnom svetu.

Kada je reč o problemskoj nastavi u nastavi pisanja na stranom jeziku, nema dovoljno literature. Mardzija Hajati Abduli (Abdullah, 1998: 2) tvrdi da problemska nastava, kao konstruktivistička metoda, podstiče studente da slušaju, govore, čitaju i pišu na stranom jeziku dok dokumentuju diskusije i odluke. Na takav način studenti konstruišu jezička znanja, ali i znanja kako se jezik koristi u kontekstu van učionice.

Gotovo da nema istraživanja o upotrebi problemske nastave kao metode $\mathrm{u}$ oblasti engleskog jezika struke. Jedni od retkih koji su se time bavili, Vud i Hed (Wood \& Head, 2004), implementirali su problemsku nastavu na kurs engleskog jezika koji su slušali studenti medicine i potvrdili uspeh primene učenja kroz rešavanje problema. Rezultati su pokazali i poboljšanje veština samousmerenog učenja (engl. self-directed learning). Ono što je od važnosti za našu studiju jeste da oni tvrde da su studenti, iako na površinskom nivou nisu pokazali bolje rezultate $u$ veštini pisanja, u svojim radovima bili više orijentisani na čitaoce (engl. audience). Međutim, oni nisu imali određen instrument kojim su merili taj aspekt. Studenti su pisali drugim studentima u grupi, koji su potvrdili da su pisali na način na koji su očekivali (2004: 12).

\section{METODOLOGIJA}

Rad ima za cilj ispitivanje stavova studenata i njihove lične procene u vezi sa razvojem veštine pisanja na kursu engleskog jezika struke.

$\mathrm{Na}$ osnovu formulisanog cilja, utvrđeni su posebni zadaci istraživanja:

1. Utvrditi da li postoji razlika u zastupljenosti stavova o razvoju globalnih aspekata pisanja (organizacije, namene, čitaoca) u odnosu na vrstu nastave (problemska u odnosu na tradicionalnu);

2. Utvrditi da li postoji razlika u zastupljenosti stavova o razvoju lokalnih aspekata pisanja (stila, gramatike, mehanike) u odnosu na vrstu nastave (problemska u odnosu na tradicionalnu).

Nulta hipoteza (H0) u radu glasi: Postoji značajna razlika u samoproceni razvoja lokalnih $i$ globalnih aspekata pisanja kod studenata u eksperimentalnoj $i$ kontrolnoj grupi.

$\mathrm{U}$ skladu sa postavljenim ciljem $\mathrm{u}$ istraživanju je primenjena eksperimentalna metoda - eksperiment s paralelnim grupama. U našem istraživanju učestvovalo je ukupno 194 studenata druge godine na Visokoj poslovnoj školi strukovnih studija u Novom Sadu. Istraživanje je sprovedeno na časovima vežbi u vežbačkim grupama koje broje oko 30 učenika. U tri vežbačke grupe (koje predstavljaju eksperimentalnu grupu u istraživanju) nastavnik je obrađivao aspekte pisanja putem učenja kroz rešavanje problema, dok su tri vežbačke grupe (kontrolna 
grupa $\mathrm{u}$ istraživanju) učile o aspektima pisanja putem tradicionalne nastave. Konačni broj studenata u eksperimentalnoj grupi bio je 98, dok je kontrolna grupa obuhvatila 96 studenata.

Kao što je navedeno, eksperimentalna grupa obrađivala je aspekte pisanja po prethodno osmišljenoj nastavnoj jedinici, pripremljenoj po principima artikulacije časa problemske nastave. $\mathrm{Na}$ osnovu rezultata teorijske analize o obrazovanju putem rešavanja problema, zaključili smo da je najefikasnije da se obrada nastavnih jedinica realizuje sledećim redosledom:

1. Postavljanje problema (problemska situacija);

2. Definisanje problema;

3. Hipoteze;

4. Dekompozicija problema (raščlanjavanje glavnog na uže probleme);

5. Rešavanje problema (verifikacija hipoteze);

6. Zaključci.

Isti sadržaji obrađeni su i u kontrolnoj grupi, ali putem predavačkoilustrativne nastavne metode. U kontrolnoj grupi nismo izrađivali posebnu skicu, već je nastavnik radio na uobičajeni način, izlaganjem i objašnjavanjem nastavne građe. Nastavnik je verbalno izlagao nastavne sadržaje, povremeno objašnjavajući razlike prikazivanjem primera dobro i loše napisanih dokumenata.

Studenti su pohađali predmet Prvi strani poslovni jezik I - engleski. Za studente prve godine smo se opredelili prvenstveno zato što zvanični nastavni plan za ovu godinu predviđa intenzivniji rad na poslovnoj korespondenciji i zato što su studenti zreli i sposobni za upoznavanje sa problemskom nastavom. U toku prvog semestra studenti na Visokoj poslovnoj školi strukovnih studija u Novom Sadu imaju obavezan predmet Prvi strani poslovni jezik I - engleski, koji upravo i čini kontekst ovog istraživanja. Naime, pomenuti predmet ima više ciljeva - razvijanje svesti o raznolikosti jezičkih sredstava i osposobljavanje studenata za njihovu aktivnu primenu u poslovnom kontekstu, razvijanje sociolingvističke i strateške kompetencije, snalaženje u pisanim formama tipičnim za struku, ovladavanje najfrekventnijim retoričkim formama koje odražavaju strukturu mišljenja u ekonomiji i poslovanju (Studijski programi osnovnih strukovnih studija - Visoka poslovna škola strukovnih studija, Novi Sad, 2009: 19). Upravo kombinacija navedenih sadržaja čini ovaj predmet pogodnim za istraživanje jer omogućava da se u nastavu implementiraju posebno konstruisane problemski modelovane nastavne jedinice. Dodatna pozitivna strana izvođenja ovog eksperimenta u prvom semestru prve godine leži u činjenici da se, ukoliko se pokaže da studenti imaju koristi od ovakve vrste nastave, ona može uključiti i u naredne godine na osnovnim strukovnim studijama.

Anketni upitnik podeljen je nakon održanih nastavnih jedinica i sadržao je osam pitanja. Njime se želelo utvrditi sledeće: studentska procena vrste nastave (prva dva pitanja) i njihova procena o razvoju globalnih i lokalnih aspekata pisanja 
(pitanja 3-8). Broj nastavnih časova (16 časova po 45 minuta, odnosno 8 blokčasova) utvrđen je na osnovu potrebe za obradom svih analiziranih aspekata pisanja.

1. nedelja - globalni aspekt organizacije - 1 blok-čas ( 2 časa)

2. nedelja - globalni aspekt namene -1 blok-čas (2 časa)

3. nedelja - globalni aspekt publike -1 blok-čas (2 časa)

4. nedelja - lokalni aspekt stila - prvi blok-čas (2 časa)

5. nedelja - lokalni aspekt stila - drugi blok-čas (2 časa)

6. nedelja - lokalni aspekt gramatike - prvi blok-čas (2 časa)

7. nedelja - lokalni aspekt gramatike - drugi blok-čas (2 časa)

8. nedelja - lokalni aspekt mehanike -1 blok-čas (2 časa)

Prilikom odabira pomenutih lokalnih i globalnih elemenata autor se vodio stavom da je neophodno da studenti, osim osnovnih konvencija pisanja, steknu i adekvatno znanje o globalnim elementima pisanja. Kako navodi Silva (Silva, 1993), postoje različita mišljenja i neslaganja o tome šta predstavlja kvalitetno pisanje. Kriterijumi koji se najčešće koriste da bi se napravila razlika između dobrog i lošeg teksta su gramatička tačnost, pravopis i interpunkcija, dobro organizovane informacije, ali Silva ističe potrebu da se fokusiramo i na makro i na mikro nivo pisanja (Silva, 1993). Veoma je važno negovanje oba nivoa, jer čitanje tekstova sa kvalitetnim sadržajem, a lošom formom, može biti neinteresantno i teško za praćenje. Stoga je autorka rada odlučila da u razmatranje uzme i lokalne i globalne aspekte pisanja. Istraživanje je obuhvatilo ispitivanje tri lokalna (stil, gramatika, mehanika) i tri globalna aspekta (organizacija, namena, čitaoci). Za svaki od navedenih aspekata napravljena je nastavna jedinica za pisanja u nastavi engleskog jezika struke.

\section{ANALIZA REZULTATA}

U tabelama koje slede najpre će biti prikazana brojčana (n) i procentualna (\%) zastupljenost odgovora na pitanja iz anketnog upitnika. Deskriptivnim postupkom je moguće samo nagovestiti neke karakteristike pojedinih odgovora studenata na pitanja iz ankete, dok će se značajnost razlike između grupe kasnije analizirati.

\begin{tabular}{lrrrrrr}
\hline \multicolumn{1}{c}{ Pitanje 1. } & & $\mathrm{Da}$ & & $\mathrm{Ne}$ & $\mathrm{Možda}$ \\
\hline & $\mathrm{N}$ & $\%$ & $\mathrm{~N}$ & $\%$ & $\mathrm{~N}$ & 20,4 \\
\hline $\begin{array}{l}\text { Eksperimentalna } \\
\text { grupa }\end{array}$ & 73. & $74,5^{*}$ & 5. & 5,1 & 20. & \\
\hline Kontrolna grupa & 42. & 43,8 & 6. & 6,3 & 48. & $50,0^{*}$ \\
\hline
\end{tabular}

Tabela 1. Brojčana (n) i procentualna (\%) zastupljenost odgovora studenata na pitanje: Da li smatrate da ste u toku nastave unapredili veštinu pisanja? u odnosu na grupe. 
$\mathrm{Na}$ osnovu dobijenih rezultata moguće je izdvojiti karakteristike svake grupe u odnosu na odgovore na pitanje: Da li smatrate da ste u toku nastave unapredili veštinu pisanja? Sledi da su studenti iz eksperimentalne grupe značajno više imali odgovora $d a^{*}$, dok se kod studenata u kontrolnoj grupi ističe odgovor možda*.

\begin{tabular}{lrrrrrr}
\hline \multicolumn{1}{c}{ Pitanje 2. } & & $\mathrm{Da}$ & $\mathrm{Ne}$ & Možda \\
\hline & $\mathrm{N}$ & $\%$ & $\mathrm{n}$ & $\%$ & $\mathrm{n}$ & $\%$ \\
\hline Eksperimentalna grupa & 86. & $87,8^{*}$ & 0. & .0 & 12. & 12,2 \\
\hline Kontrolna grupa & 53. & 55,2 & 10. & $10,4^{*}$ & 33. & $34,4^{*}$ \\
\hline
\end{tabular}

Tabela 2. Brojčana (n) i procentualna (\%) zastupljenost odgovora studenata na pitanje: Da li mislite da sistem po kom ste radili može da doprinese većoj motivisanosti studenata? $\mathrm{u}$ odnosu na grupe.

U odnosu na pitanje: Da li mislite da sistem po kom ste radili može da doprinese unapređenu veštine pisanja? eksperimentalna grupa ima statistički više izraženih odgovora $d a^{*}$, dok kontrolna grupa ima više izraženo svojstvo odgovor

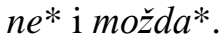

\begin{tabular}{lrrrrrr}
\hline \multicolumn{1}{c}{ Pitanje 3. } & & $\mathrm{Da}$ & & $\mathrm{Ne}$ & & Možda \\
\hline & $\mathrm{n}$ & $\%$ & $\mathrm{n}$ & $\%$ & $\mathrm{n}$ & $\%$ \\
\hline $\begin{array}{l}\text { Eksperimentalna } \\
\text { grupa }\end{array}$ & 65. & $66,3^{*}$ & 4. & 4,1 & 29. & 29,6 \\
\hline Kontrolna grupa & 29. & 30,2 & 27. & $28,1^{*}$ & 40. & $41,7^{*}$ \\
\hline
\end{tabular}

Tabela 3. Brojčana (n) i procentualna (\%) zastupljenost odgovora studenata na pitanje: Da li smatrate da ste naučili o nameni poslovnih dokumenata? u odnosu na grupe.

Slične odgovore studenti su dali i u odnosu na pitanje: Da li smatrate da ste naučili o nameni poslovnih dokumenata? Značajno veći broj studenata $\mathrm{u}$ eksperimentalnoj grupi je dao odgovor $d a^{*}$, dok kod studenata u kontrolnoj grupi dominiraju odgovori $n e^{*}$ i možda*.

\begin{tabular}{lrrrrrr}
\hline \multicolumn{1}{c}{ Pitanje 4. } & $\mathrm{Da}$ & & $\mathrm{Ne}$ & & Možda \\
\hline \multicolumn{1}{l}{$\begin{array}{l}\text { Eksperimentalna } \\
\text { grupa }\end{array}$} & $\mathrm{N}$ & $\%$ & $\mathrm{n}$ & $\%$ & $\mathrm{~N}$ & $\%$ \\
\hline Kontrolna grupa & 16. & $16,9^{*}$ & 7. & 7,1 & 47. & 48,0 \\
\hline
\end{tabular}

Tabela 4. Brojčana (n) i procentualna (\%) zastupljenost odgovora studenata na pitanje: Da li smatrate da ste naučili o aspektu čitalaca poslovnih dokumenata? u odnosu na grupe.

Uvidom u Tabelu 4, u kojoj su prikazani odgovori na pitanje: $D a l i$ smatrate da ste naučili o aspektu čitalaca poslovnih dokumenata? sledi da su 
studenti u eksperimentalnoj grupi smatrali da su poboljšali znanje o aspektu čitalaca, dok su studenti u kontrolnoj grupi imali suprotan stav.

\begin{tabular}{lrrrrrr}
\hline \multicolumn{1}{c}{ Pitanje 5. } & $\mathrm{Da}$ & & $\mathrm{Ne}$ & & Možda \\
\hline \multicolumn{1}{l}{$\begin{array}{l}\text { Eksperimentalna } \\
\text { grupa }\end{array}$} & 55. & $56,1^{*}$ & 7. & 7,1 & 36. & 36,7 \\
\hline Kontrolna grupa & 33. & 34,4 & 32. & $33,3^{*}$ & 31. & 32,3 \\
\hline
\end{tabular}

Tabela 5. Brojčana (n) i procentualna (\%) zastupljenost odgovora studenata na pitanje: Da li smatrate da ste naučili o organizaciji poslovnih dokumenata? u odnosu na grupe.

Na pitanje broj 5,6 . i 7. (Tabele $5,6,7$ ) studenti su dali slične odgovore. Studenti iz eksperimentalne grupe, koji su bili izloženi problemskoj nastavi, dali su potvrdne odgovore u vezi sa doprinosom date metode razvoju aspekta organizacije, stila, gramatike, dok kod studenata iz kontrolne grupe, koji su navedene aspekte pisanja obrađivali tradicionalnom metodom, preovladava odgovor $n e^{*}$.

\begin{tabular}{lrrrrrr}
\hline \multicolumn{1}{c}{ Pitanje 6. } & & $\mathrm{Da}$ & & $\mathrm{Ne}$ & $\mathrm{n}$ & Možda \\
\hline \multicolumn{1}{l}{$\begin{array}{l}\text { Eksperimentalna } \\
\text { grupa }\end{array}$} & $\mathrm{N}$ & $\%$ & $\mathrm{~N}$ & $\%$ & $\%$ \\
\hline Kontrolna grupa & 39. & $62,2^{*}$ & 7. & 7,1 & 30. & 30,6 \\
\hline
\end{tabular}

Tabela 6. Brojčana (n) i procentualna (\%) zastupljenost odgovora studenata na pitanje: Da li smatrate da ste naučili o stilu poslovnih dokumenata? u odnosu na grupe.

\begin{tabular}{lrrrrrr}
\hline \multicolumn{1}{c}{ Pitanje 7. } & & $\mathrm{Da}$ & $\mathrm{Ne}$ & & Možda \\
\hline \multicolumn{1}{l}{$\begin{array}{l}\text { Eksperimentalna } \\
\text { grupa }\end{array}$} & 81. & $82,7^{*}$ & 4. & 4,1 & 13. & 13,3 \\
\hline Kontrolna grupa & 60. & 62,5 & 21. & $21,9^{*}$ & 15. & 15,6 \\
\hline
\end{tabular}

Tabela 7. Brojčana (n) i procentualna (\%) zastupljenost odgovora studenata na pitanje: Da li smatrate da ste unapredili znanja iz gramatike? u odnosu na grupe.

\begin{tabular}{lrrrrrr}
\hline \multicolumn{1}{c}{ Pitanje 8. } & $\mathrm{Da}$ & & $\mathrm{Ne}$ & & Možda \\
\hline \multicolumn{1}{l}{$\begin{array}{l}\text { Eksperimentalna } \\
\text { grupa }\end{array}$} & 60. & $61,2^{*}$ & 4. & 4,1 & 34. & 34,7 \\
\hline Kontrolna grupa & 28. & 29,2 & 24. & $25,0^{*}$ & 44. & 45,8 \\
\hline
\end{tabular}

Tabela 8. Brojčana (n) i procentualna (\%) zastupljenost odgovora studenata na pitanje: Da li smatrate da ste unapredili znanja iz mehanike pisanja? u odnosu na grupe. 
U odnosu na pitanje: Da li smatrate da ste unapredili znanja iz mehanike pisanja? eksperimentalna grupa ima statistički više izraženo svojstvo odgovor da*, dok kontrolna grupa ima statistički više izraženo svojstvo odgovor ne* $i$ možda*.

Tabela 9. predstavlja analizu razlika između eksperimentalne i kontrolne grupe u samoproceni razvoja aspekata pisanja.

\begin{tabular}{rrrr}
\hline Analiza & $\mathrm{N}$ & $\mathrm{F}$ & $\mathrm{p}$ \\
\hline MANOVA & 8 & 10.787 & .000 \\
\hline Diskriminativna & 8 & 10.728 & .000 \\
\hline
\end{tabular}

Tabela 9. Značajnost razlike između grupe ispitanika u odnosu na odgovore na pitanja

$\mathrm{Na}$ osnovu vrednosti $\mathrm{p}=.000$ (analize MANOVA) i $\mathrm{p}=.000$ (diskriminativne analize), prihvata se nulta hipoteza $\mathrm{H}_{0}$ što znači da postoji razlika $\mathrm{i}$ jasno definisana granica između dve grupe ispitanika.

Koeficijenat diskriminacije (k.dsk) upućuje da je razlika u stavovima između eksperimentalne i kontrolne grupe u odnosu na pitanja iz upitnika najveća kod pitanja Da li smatrate da ste naučili o nameni poslovnih dokumenata? (.042), a da slede pitanja: Da li smatrate da ste unapredili znanja iz gramatike? (.037); Da li smatrate da ste unapredili znanja iz mehanike pisanja? (.027); Da li mislite da sistem po kom ste radili može da doprinese unapređenju veštine pisanja? (.026); Da li smatrate da ste u toku nastave unapredili veštinu pisanja? (.024); Da li smatrate da ste naučili o aspektu čitalaca poslovnih dokumenata? (.011); Da li smatrate da ste naučili o organizaciji poslovnih dokumenata? (.008); Da li smatrate da ste naučili o stilu poslovnih dokumenata? (.000).

\begin{tabular}{rrrrrr}
\hline & & $\mathrm{R}$ & $\mathrm{F}$ & $\mathrm{p}$ & k.dsk \\
\hline pit 1 & .305 & .321 & 22.018 & .000 & .024 \\
\hline pit 2 & .353 & .377 & 31.869 & .000 & .026 \\
\hline pit 3 & .379 & .410 & 38.764 & .000 & .042 \\
\hline pit 4 & .352 & .376 & 31.630 & .000 & .011 \\
\hline pit 5 & .318 & .336 & 24.408 & .000 & .008 \\
\hline pit 6 & .268 & .278 & 16.102 & .000 & .000 \\
\hline pit 7 & .266 & .276 & 15.870 & .000 & .037 \\
\hline pit 8 & .351 & .374 & 31.291 & .000 & .027 \\
\hline
\end{tabular}

Tabela 10. Značajnost razlike između grupe ispitanika u odnosu na pitanja iz anketnog upitnika

Tabela 11. pruža uvid u odnos i karakteristike svake grupe ispitanika $\mathrm{u}$ odnosu na diskriminativna obeležja, to jest odgovore na pitanja iz ankete. Prva tri pitanja po kojima se eksperimentalna i kontrolna grupa najviše razlikuju, to jest, pitanja na koja su studenti iz eksperimentalne i kontrolne grupe dali različite odgovore su pitanja koja se odnose na procenu razvoja globalnog aspekta namene praćene lokalnim aspektima gramatike i mehanike. Uvidom u tabelu može se uočiti 
da studenti iz eksperimentalne grupe imaju statistički značajno više odgovora $d a \mathrm{u}$ odnosu na broj pozitivnih odgovora od strane studenata u kontrolnoj grupi, dok su studenti iz kontrolne grupe imali statistički značajno veći broj odgovora ne u odnosu na broj negativnih odgovora od strane studenata u eksperimentaljnoj grupi.

\begin{tabular}{|c|c|c|c|}
\hline \multicolumn{2}{|c|}{ Eksperimentalna } & Kontrolna & $\mathrm{dpr} \%$ \\
\hline pit 3 & da* & $\begin{array}{r}\text { ne*, } \\
\text { možda* }\end{array}$ & 24.000 \\
\hline pit 7 & $\mathrm{da}^{*}$ & ne* & 21.143 \\
\hline pit 8 & $\mathrm{da}^{*}$ & ne* & 15.429 \\
\hline pit 2 & da* & $\begin{array}{r}\text { ne*, } \\
\text { možda* }\end{array}$ & 14.857 \\
\hline pit 1 & $\mathrm{da}^{*}$ & možda* & 13.714 \\
\hline pit 4 & $\mathrm{da}^{*}$ & $n e^{*}$ & 6.286 \\
\hline pit 5 & $\mathrm{da}^{*}$ & ne* & 4.571 \\
\hline pit 6 & da* & ne* & .000 \\
\hline
\end{tabular}

Tabela 11. Karakteristike grupe ispitanika u odnosu na samoprocenu razvoja aspekata pisanja

Anketom je utvrđeno da su studenti iz eksperimentalne grupe imali pozitivan odnos prema problemskom pristupu. Učenje je bilo usmereno ka dubljim nivoima razumevanja i lične smislenosti i iz tog razloga studenti su procenili da je bilo efikasno. Problemska nastava brine o afektivnim potrebama studenata, naglašavajući potrebu za smanjenjem anksioznosti i napetosti, koje ometaju rad i stvaraju otpor prirodnom usvajanju i učenju jezika. Zaključak je da problemski pristup može smanjiti napetost i pomoći u stvaranju opuštenije atmosfere za učenje. $\mathrm{U}$ tradicionalnoj nastavi uobičajeno je da nastavnik kontroliše nastavu. Ovo, u izvesnoj meri, dovodi do napetosti i anksioznosti i utiče na njihov doprinos i učešće u učenju. Problemski modelovane nastavne jedinice su stvorile atmosferu vršnjačkog učenja. Kroz deljenje ideja, studenti su naučili i stekli mnoštvo znanja radeći na autentičnim primerima. U početku su studenti istražili svoje poznate i nepoznate oblasti. Da bi pojasnili svoje nepoznate delove, oni su morali da traže informacije i razgovaraju sa drugim studentima u grupi. Učeći na ovaj način, studenti su, u izvesnoj meri, bili spremni da znanje koje su stekli podele sa kolegama iz grupe, stekli su poverenje u sebe i druge i bili su uključeni u svaki korak u procesu učenja.

Aspekti koji zauzimaju prva tri mesta prema rezultatima (vidi Tabelu 11) su: globalni aspekt namene i lokalni aspekti gramatike i mehanike. Ovakav rezultat je logičan zato što globalni aspekti pisanja podrazumevaju reorganizovanje naučenih sadržaja, analizu i primenu u novim situacijama. Literatura navodi (Gieve 1998; Rollinson 2005) da problemska nastava podstiče razvoj intelektualnih veština višeg reda i kreativno razmišljanje, koji su u vezi sa globalnim aspektima pisanja, ali činjenica da su studenti pozitivno procenili poboljšanje lokalnih aspekata 
gramatike i mehanike sugeriše da i lokalni aspekti pisanja mogu biti unapređeni problemskom nastavom.

Pozitivna samoprocena razvoja aspekata gramatika $i$ mehanika $\mathrm{u}$ eksperimentalnoj grupi objašnjenje nalazi u studijama koje su ispitivale efekte direktne (kada nastavnik identifikuje i ispravlja grešku) i indirektne povratne informacije (nastavnik određuje greške, ali zahteva od studenata da isprave grešku, a u nekim slučajevima i da identifikuju vrstu greške) na poboljšanje veštine pisanja (Ferris \& Hedgcock, 2005). Generalno, istraživanja pokazuju da je indirektna povratna informacija superiorna u odnosu na direktnu jer dovodi „do većeg kognitivnog angažmana, refleksije i rešavanja problema" kod studenata (Ferris, 2002: 19). Problemska nastava je omogućila da nastavnik da povratnu informaciju u više faza procesa pisanja, ne samo u fazi pregledanja; $i$ da se bavi ne samo gramatičkim greškama, već brojnim aspektima pisanja što je dovelo do poboljšanja ovog aspekta.

Statistički značajno veći broj odgovora ne na pitanja iz anketnog upitnika kod studenata iz kontrolne grupe u odnosu na broj studenata iz eksperimentalne grupe koji su na ista pitanja odgovorili sa ne svoje objašnjenje nalazi u stavovima teoretičara (Freedman, 1994; Dudley-Evans, 1998), koji su izrazili stav da eksplicitna nastava može biti kontraproduktivna jer ograničava učenike da aktivno učestvuju u procesu pisanja i da izraze svoje ideje kreativno. Oni smatraju da će učenici nastaviti da očekuju da im se pokaže kako da pišu određene vrste tekstova, da će smatrati da je potrebno da pišu u skladu sa strogo definisanom formulom što bi sprečilo njihovo postepeno osamostaljivanje, a samim tim i sticanje poverenja $u$ vlastite sposobnosti.

U skladu sa radovima koji su prethodno pomenuti u radu (Bandura, 1986, Shell, Murphy \& Bruning, 1989, Pajares \& Valiante, 1997) i koji ukazuju na uticaj samoprocene na efikasnost veštine pisanja, a pozivajući se na rezultate sprovedene ankete, koja pokazuje da studenti koji su bili izloženi problemskoj nastavi mnogo bolje procenjuju svoje znanje vezano za svaki aspekt pisanja i motivisanost datom metodom, svakako da bolji rezultati koje su postigli studenti eksperimentalne grupe mogu imati osnove u većoj sigurnosti studenata u svoju veštinu pisanja.

\section{ZAKLJUČAK}

Studenti su pozitivno procenili razvijanje svih aspekata veštine pisanja na kursu jezika struke na kom je bila implementirana problemska nastava. Instrukcija, uključujući kombinovanje objašnjenja sa pružanjem primera, davanje instrukcija o određenim strategijama, postavljanjem specifičnih kratkoročnih i dugoročnih ciljeva i davanje eksplicitnih povratnih informacija mogu da posluže kao izvori informacija koji mogu poboljšati razvoj samoefikasnosti. Svi navedeni elementi prisutni su u problemskoj nastavi.

Primena problemske nastave tek je počela da se ispituje u oblastima kao što je engleski jezik struke. Problemsku nastavu potrebno je uključiti u nastavu jezika 
struke, jer neguje timski rad i kolaboraciju i zahteva originalno i kritičko razmišljanje, što je od ključnog značaja na radnom mestu. Kroz rad na komunikativnim zadacima, uz obavezno čitanje dodatnih referentnih materijala, studenti unapređuju veštine razmišljanja višeg reda. Međutim, s obzirom na posebne odlike studenata stranih jezika (na primer, nivo znanja, vremenska ograničenost i motivacija), nastavnici će morati neke principe problemske nastave da promene i prilagode studentima, a da istovremeno predstave suštinu problemske nastave.

\section{LITERATURA}

Bandura, A. (1986). Social foundations of thought and action: A social cognition theory. Englewood Cliffs, NJ: Prentice Hall.

Bandura, A. (1997). Self-efficacy: The exercise of control. San Francisko, CA: W.H. Freeman Publishing.

Broaddus, M. B. (2012). "Students' writing self-efficacy, motivation, and experience: Predictors in journalism education". Pristupljeno 15.4.2018. URL: http://trace.tennessee.edu/utk_graddiss/1275

Dudley-Evans, T., \& Johns, M. (1998). Developments in ESP: A multidisciplinary approach. Cambridge: Cambridge University Press.

Early, J. S., \& DeCosta-Smith, M. (2011). "Making a case for college: A genrebased college admission essay intervention for underserved high school students". Journal of Writing Research 2(3): 299-329.

Ferris, D. (2002). Treatment of error in second language student writing. Ann Arbor, MI: University of Michigan Press.

Ferris, D., \& Hedgcock, J. (2005). Teaching ESL composition: Purpose, process and practice (2nd ed.). Mahwah, NJ: Lawrence Erlbaum Associates.

Freedman, A. (1993). "Show and tell? The role of explicit teaching in the learning of new genres". Research in the Teaching of English 27(3): 222-251.

Gieve, S. (1998). "Comments on Dwight Atkinson's "A critical approach to critical thinking in TESOL". TESOL Quarterly 32: 123-129.

He, T. (2005). "Effects of Mastery and Performance Goals on the Composition Strategy Use of Adult EFL Writers". Canadian Modern Language Review 61(3): 407-431.

Hmelo-Silver, C. E. \& Barrows, H. S. (2006). "Goals and strategies of a problembased learning facilitator". Interdisciplinary Journal of Problem-based Learning 1: 21-39.

Hmelo-Silver, C. E. (2004). "Problem-based learning: What and How Do Students Learn?". Educational Psychology Review 16 (3): 235-266.

Loyens, S., Magda, J., \& Rikers, R. (2008). "Self-Directed Learning in ProblemBased Learning and its Relationships with Self-Regulated Learning". Educational Psychology Review 20(4): 411-427. 
Pajares, F., \& Johnson, M. (1996). "Self-efficacy beliefs and the writing performance of entering high school students". Psychology in the Schools 33: $163-175$.

Pajares, F., \& Valiante, G. (1997). "Influence of self-efficacy on elementary students' writing". Journal of Educational Research 90: 353-360.

Shah, P., Mahmud, W., Din, R., Yusof, A., \& Pardi. K. (2011). "Self-Efficacy in the Writing of Malaysian ESL Learners". World Applied Sciences Journal (Innovation and Pedagogy for Lifelong Learning) 15: 08-11.

Rahimpour, M., \& Nariman-Jahan, R. (2010). "The influence of self-efficacy and proficiency on EFL learners' writing". International Journal of Instructional Technology and Distance Learning 7(11): 19-32.

Rollinson, P. (2005). "Using peer feedback in the ESL writing class". ELT Journal 59: 23-30.

Shell, D., Murphy, C., \& Bruning, R. (1989). "Self-efficacy, attributions, and outcome expectancy mechanisms in reading and writing achievement". Journal of Educational Psychology 81: 91-100.

Silva, T. (1993). "Toward an understanding of the distinct nature of L2 writing: The ESL research and its implications". TESOL Quarterly 27(4): 657-675.

Stepanovna, A. (2006). "O inovacionim i tradicionalnim modelima nastavnog preocesa". Nastava i vaspitanje 2: 109-122.

Weimer, M. (2002). Learner-centered teaching: Five key changes to practice. San Francisco, CA: Jossey-Bass.

Ivana M. Martinović Barbul

Novi Sad School of Business

University of Novi Sad

Faculty of Philosophy

PhD studies in teaching methodology

\section{SELF-EFFICACY, PROBLEM BASED LEARNING AND WRITING SKILLS}

\section{Summary}

The aim of this paper was to examine the level of self-efficacy in an ESP writing course. This study was carried on the sample of 194 students at Novi Sad School of Business. The instrument used was questionnaire.

In the experimental group, students were taught about the local and global aspects of writing with pre-planned teaching units prepared according to the principles of the PBL implementation. The same contents were taught in the control group by a traditional method. The teacher orally presented the content, sometimes explaining the difference by showing examples of well and poorly written business documents.

Based on the $\mathrm{p}$ values, $\mathrm{p}=.000$ (MANOVA analysis) and $\mathrm{p}=.000$ (discriminatory analysis), hypothesis $\mathrm{H} 1$ is rejected and an alternative hypothesis A1 is accepted. This means that there is a difference and a clearly defined boundary between the groups. The 
biggest difference in the students' responses is found in questions related to the development of local aspect 'purposes' and the global aspect of grammar and mechanics. Students in the control group negatively evaluated the development while the students in the experimental group positively assessed the development of the above aspects. Regarding the aspect of purpose, this result is logical because global aspects of writing involve the reorganization of the learned content, analysis and application in new situations. As cited in literature (Gieve, 1998; Rollinson, 2005), problem-based teaching encourages the development of intellectual higher-order skills and creative thinking related to global aspects of writing, but the fact that students have positively assessed the improvement of local aspects of grammar and mechanics suggests that local aspects of writing can be enhanced by problem based learning.

Key words: self-efficacy, problem-based learning, teaching writing, local and global aspects.

Primljeno: 30. 4. 2018. Prihvaćeno: 11. 7. 2018. 